\title{
Studies on the implementation of System Application Product (SAP) Materials Management (MM Module) for financial support in Sugar cane cultivation
}

\author{
S. Chandraju' ${ }^{1}$ B. Raviprasad ${ }^{2}$, C. S. Chidan Kumar ${ }^{3}$ \\ ${ }^{1,2}$ Department of Studies in Sugar Technology, Sir M. Vishweshwaraya Post graduate Center, University of \\ Mysore, Tubinskere - 571402,Mandya, Karnataka, India. \\ ${ }^{3}$ Department of Chemistry, Alva's Institute of Engineering \& Technology, Shobhavana Campus, Mijar, \\ Moodbidri - 574225, South CanaraDt.Karnataka, India
}

\begin{abstract}
In traditional mode of cane cultivation, harvesting and transportation of cane from the plot to the factory involves various steps and lot of paper work and requires more man power. In addition to this, farmers also facing lot of problems to provide all the information's throughout the course of cultivation.In order to provide financial assistance, the sugar industries are providing loan facility tie-up with Bankers.All these process is adopting System Application Product (SAP) Materials Management (MM-MODULE) to monitor in a single window. This will helps the farmers and factories are able to get benefitted and in the mean time Bank will also mutually benefitted by getting interest and increase their business volume. Hence by implementing System Application Product(SAP), once entering the data in the system it is continued further deletion of data from the system administrator. Due to this farmers need not required to submit all the stipulated forms in all the times. More over thelead time required is very less.
\end{abstract}

Keywords -System Application Product, Materials Management, Tie up letter, Trip Sheet, Cane weighment ticket

\section{Introduction}

India is mainly constituted with villages and Agriculture is the main occupation. Sugar cane cultivation is one of the important commercial crops adopted by the farmers. The demand of sugar consumption is regularly increasing day by day as aresult more and more sugar industries are coming up in turn there is ascope for further increase in the sugar cane cultivation throughout the country. But the farmers cannot afford to bear the expenditure incurred for the cultivation of sugarcane due to hike in cultivation cost such as increase in fertilizer price, manual labour, pesticides, insecticides, transportation etc. As a result the farmers are badly needed the financial support. In this regard sugar industries are tie up with financial institutions, Bank to get the financial assistance to farmers under the guarantee of the company. The banks provide financial support to the farmers and recover the principal amount with interest while factory is made the payment to the farmers after the supply of cane. In order to obtain financial support from the Bank, various procedures/steps to be followed.

\subsection{Organization chart of cane section}

\section{Material And Methods}

The field Assistant of Sugar industry contacts the farmers and takes the measurement of area of plantation of sugar cane by individual farmers and made the agreement between the farmers and the sugar industry. Then the action will be taken to provide financial assistance tie-up with Banks.

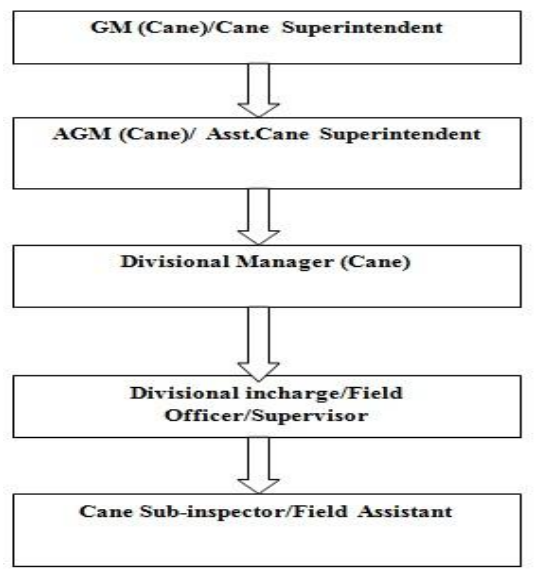



Procedure for extending the loan facility to farmers by Sugar industry is as follows.

\subsection{Agreement for sale and procurement of sugar cane}

This is a type of binding between the farmer and the factory for supply of cane from the farmers or procurement/purchase of cane from the factory. This is a mutual understanding in the form of written document. The format of Agreement for sale and procurement of sugar cane is as follows.

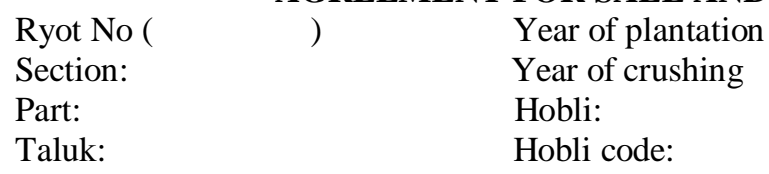

Taluk code:

\section{SCHEDULE}

\begin{tabular}{|c|c|c|c|c|c|c|c|c|c|c|}
\hline $\begin{array}{c}\text { Plo } \\
\mathrm{t} \\
\text { No. }\end{array}$ & $\begin{array}{c}\text { Plac } \\
\text { e of } \\
\text { crop } \\
\& \\
\text { code }\end{array}$ & $\begin{array}{c}\text { Surve } \\
\text { y No. }\end{array}$ & & Breed & \multicolumn{2}{|c|}{$\begin{array}{c}\text { Registered Area in } \\
\text { acre }\end{array}$} & $\begin{array}{c}\text { Date of } \\
\text { cane } \\
\text { cuitivat } \\
\text { ed }\end{array}$ & $\begin{array}{c}\text { Agreed } \\
\text { cane } \\
\text { qty. In } \\
\text { MTs }\end{array}$ & $\begin{array}{c}\text { Dista } \\
\text { nce }\end{array}$ & $\begin{array}{c}\text { Method } \\
\text { of } \\
\text { cultivat } \\
\text { ion }\end{array}$ \\
\hline & & & & & Fresh & Second & & & & \\
\hline & & & & & & & & & & \\
\hline
\end{tabular}

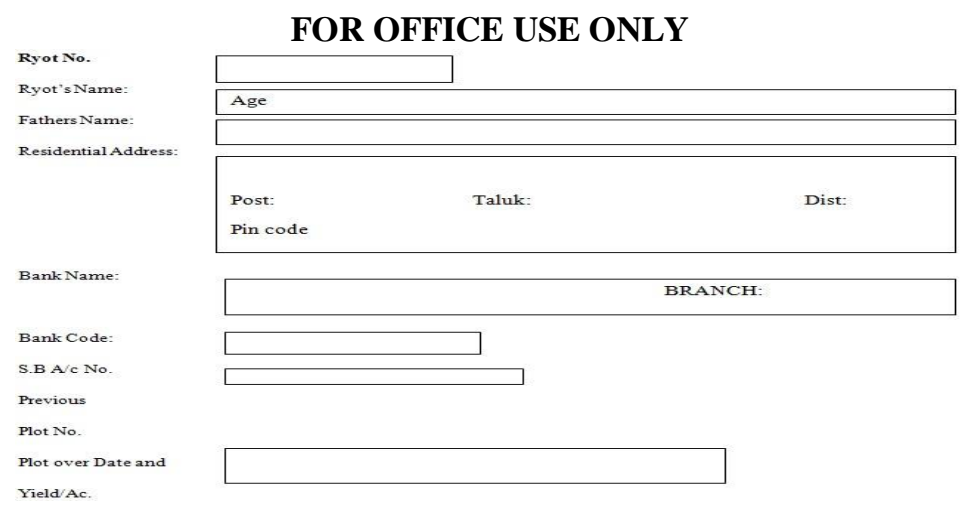

Previous Seasons-Cane Regn.\& Supply Particulars

\begin{tabular}{|l|l|l|l|l|l|}
\hline Sl.No & Cr.Season & \multicolumn{2}{|l|}{ Regd/U.R Cane } & Cane Supply(in MTS) & Perished/Diverted \\
\hline & & Plot Nos & Extent & & \\
\hline & & \multicolumn{2}{l}{} & & \\
\hline
\end{tabular}

Cane Sub-Inspector/Cane Inspector

Divisional clerk

Keened on:

Registration Clerk

\subsection{On demand pronote}

This is type of demand/request from the farmer for getting crop loan from the factory for the purpose of growing the crop in a healthy manner by way of to purchase mainly chemical manures. The format is attached below.

\section{ON DEMAND PRONOTE}

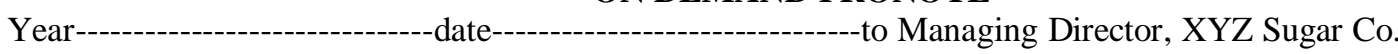

refund the amount Rs.

-that I heeby agreed to whenever you called for.

Rs,

Signature of Witness

(Ryot No.------------) wth interest @ the rate of ------received towards agricultural expenses
(Ryol
farmer

(Ryot No.------------)

Signature

of the 
2.4 Tie-Up letter

After agreement, filled loan form is submitted to factory for approval (tie-up letter).after obtaining tie-up approval letter from the factory,it is submitted to Bank for further procedures.

Ryo No./Name

$\mathrm{F} / \mathrm{H}$ Name

Format of Tie-up letter.

Resi.Village :

\begin{tabular}{|l|l|l|l|l|l|}
\hline Planting village & Plot No. & Survey No. & Variety & P(Extent)R & Date of P/R \\
\hline & & & & & \\
\hline
\end{tabular}

SUPPLIES MADE BY XYZ SUGARS.LTD.

\begin{tabular}{|l|l|l|l|l|l|l|l|}
\hline Details & Uom & Qty & Rate & Cost(Rs.) & $\begin{array}{l}\text { Credit to } \\
\text { XYZ Ltd }\end{array}$ & $\begin{array}{l}\text { Cash to } \\
\text { Ryot }\end{array}$ & Total(Rs) \\
\hline & & & & & & & \\
\hline
\end{tabular}

\section{MANAGER-CANE}

\subsection{Shifting of cane}

After completion of cutting process,there also some procedures for lifting of cane to the factory.i.e the farmer has to come to Divisional office to collect trip sheet with cutting order and make arrangement for lorry/trucks. Then it will go to weigh bridge to get weighmentticket( 2 Nos) one for lorry and other one for farmers.

\section{The specimen copy of trip.}

No.

\section{LORRY TRIP SHEET}

Section:

Date:

Ryot No-Plot No.-Name

\begin{tabular}{|c|c|c|}
\hline Ryot No & Plot No. & Name \\
\hline & & \\
\hline
\end{tabular}

Sending Time from section:

G.L.No.

Senders Name :

Cutting Rate

Reaching Time :

Sign. Of Transport clerk

\subsection{Cane weighment ticket}

This is a type of token issued at cane weighment section regarding total quantity of cane supplied by the farmer. Based $\mathrm{n}$ this only the payment is calculated and remitted to bank/formers. The format is attached below.

XYZ SUGARS LTD.

CANE WEIGHMENT TICKET

PLACE:

\begin{tabular}{|l|l|l|}
\hline Seriol No. Division & \multicolumn{1}{c|}{ Section: } & \multicolumn{1}{c|}{ WEIGHMENT DETAILS } \\
Ryot No : & Plot No. $:$ Acres: & \multicolumn{1}{c|}{ Tonnes } \\
Ryot Name : & Extent & IN-Weight : \\
Father Name : & P/R Date : & Out- Weight: (-) \\
Fillage Name : & Variety : & \\
\hline Gang leader No : & Plant/Ratoon & Gross Weight : \\
Cutting Rate Rs. & LR/TR/ADV. No : & Binders Weight : \\
& Transport Rate Rs. : & Net Weight $:$ \\
\hline
\end{tabular}


Studies on the implementation of System Application Product (SAP) Materials Management (MM

\subsection{Sugar cane supply Bill}

This is a type of voucher for making the payment to the farmers for supply of sugar cane supplied to the factory through bank which is tie-up to the factory. Once payment is received from the factory,the crop loan recovered along with interest and balance amount is issued to the concerned farmer.

\begin{tabular}{|c|c|c|c|}
\hline \multicolumn{4}{|c|}{$\begin{array}{c}\text { Format of sugar cane supply bill } \\
\text { XYZ sugars Ltd } \\
\text { SUGAR CANE SUPPLY BILL }\end{array}$} \\
\hline \multicolumn{2}{|c|}{ Ryot No/Plot No:BL03049/HRD 0208} & \multicolumn{2}{|l|}{ Season: 2011-12 } \\
\hline \multicolumn{2}{|c|}{ Division/Section: BANG/HRD } & \multicolumn{2}{|c|}{ Bill No/Bill Date: $12340 / 05-01-2012$} \\
\hline \multicolumn{2}{|c|}{ Ryot Name: ABCD } & \multicolumn{2}{|c|}{ Dt.of plant/Ratoon: 15-05-2010 Variety:8371 } \\
\hline \multicolumn{2}{|c|}{ Father/Husband's Name: ABC123 } & \multicolumn{2}{|c|}{ Extent:3.0 Acre P/R: P } \\
\hline \multicolumn{2}{|c|}{ Village: PQRST } & \multicolumn{2}{|c|}{ Plot over Date:17-04-2011 Distance: 6} \\
\hline \multicolumn{2}{|c|}{ Bank Code/Name: INB0002/ABCD BANK } & \multicolumn{2}{|c|}{ S.B.A/c No. $* * * * * *$} \\
\hline \multicolumn{4}{|c|}{ Branch Name; INB-BANG } \\
\hline \multicolumn{2}{|c|}{ CANE SUPPLIED DETAILS } & \multicolumn{2}{|c|}{ SEEDCANE SUPPLIED DETAILS } \\
\hline \multirow[t]{3}{*}{$\begin{array}{l}\text { Cane } \\
\text { Proceeds/MT(Rs): } \\
2000.00\end{array}$} & Gross Wt. 120.00 & \multicolumn{2}{|c|}{ Seedcane Proceeds/Mt(Rs):150.00/MT } \\
\hline & $\begin{array}{ll}\text { Less } & \text { Binders } \\
\text { Wt.1.120 } & \end{array}$ & \multirow{2}{*}{\multicolumn{2}{|c|}{ Seedcane Supplied Qty: }} \\
\hline & Net Wt. 118.88 & & \\
\hline \multicolumn{2}{|c|}{$\begin{array}{l}\text { CREDIT } \\
\end{array}$} & RATE Rs. & AMOUNT Rs. \\
\hline \multicolumn{2}{|c|}{$\begin{array}{l}\text { 1. Sugar cane proceeds incl. purchase tax } \\
\text { subsidy and all other statutory payments }\end{array}$} & 2000.00/MT & 237760.00 \\
\hline \multicolumn{4}{|c|}{ 2. Diverted Cane Supply Credit } \\
\hline \multicolumn{4}{|c|}{ 3. Seedcane Proceeds } \\
\hline \multicolumn{4}{|c|}{ 4.Cane Transport Subsidy } \\
\hline \multicolumn{4}{|c|}{ 5.Amount received } \\
\hline \multicolumn{4}{|c|}{ 6.Dues adjusted of other Season } \\
\hline \multicolumn{4}{|c|}{ 7.Cash receipt of Seedcane/other dues } \\
\hline \multicolumn{4}{|c|}{ 8. Others } \\
\hline & TAL & & 237760.00 \\
\hline & BIT & RATE Rs, & AMOUNT Rs. \\
\hline 1.Seedcane Debit & & 150.00/MT & 18000.00 \\
\hline 2. Amount received & rough crop loan & 15000/Acre & 45000.00 \\
\hline 3.Cane Transport ch & & $71.00 / \mathrm{MT}$ & 8520.00 \\
\hline 4. Low Tonnage $\mathrm{Wt}$ & & & \\
\hline 5.Harvesting Advan & & & 25000.00 \\
\hline 6.Fertilizer Debit & & & \\
\hline 7.Chemicals Debit & & & \\
\hline 8.Last/Next Season & des Transferred & & \\
\hline 9.Bank interest char & & $9 \% \mathrm{PA}$ & 4050.00 \\
\hline 10.Misc.Amount & & & \\
\hline 11.Payment already & ade & & \\
\hline & otal & & 100570.00 \\
\hline & Paid & & 137190.00 \\
\hline Rupees: One lakh T & ty Seven thousand one & dred ninety only & \\
\hline $\begin{array}{l}\text { Prepared by } \\
\text { ACCOUNTS }\end{array}$ & PAYMENT THROU & JH BANK & AGER- \\
\hline
\end{tabular}

All these are managed/maintained in a transparent way by single window.

\section{Results}

3.1 Implementation of SAP in cane cultivation Harvesting and shifting of cane

In order to overcome all the above mentioned traditional methods of cane harvesting, cane cutting and shifting of cane to the factory by way of modernized/computerized by implementing SAP (MM-module). 
Studies on the implementation of System Application Product (SAP) Materials Management (MM

Once the agreement has made between the farmer and the company all the information are uploaded in the system and the data has been transferred to all the cane sections which is shown in the organization chart above. In the meantime ID number is allotted to each ryot who made the agreement. This is the unique ID number given to particular ryot which is non-transferrable and this will be continued till the death of the farmer unless the rights/ documents are transferred to party's wife or children.

By feeding this unique ID number,all the details/informationof the particular ryot is displayed on the system. This information comprises of

1. Village

2. Sector

3. Area of the land

4. Date of Agreement

5. Date of Cultivation

6. $\quad$ Fresh/Ratoon cane

7. Crop loan details if availed

\section{IV.DISCUSSIONS}

The solution from SAP is bound to get the following advantages in sugar industries.

* Total integrated reliable and real time solution

SAP is user friendly i.e information will be obtained as and when required.

* Continues maintaining and evaluation of performances

The complete process of cane cultivation to shifting of cane can be monitored and evaluate by system only.

* Effective inventory control

The holding stock can be accessed and based on this; action can be taken for procurement of needy items.

* Maximize the utilization of resource

With the help of SAP solution we can utilize the existing resources in the company and avoid unnecessary losses.

\section{* Gain edge in global competence}

By implementing of SAP, losses can be avoided, recovery has been improved and the company can compete in global level.

\section{TOTAL ADVANTAGES BY IMPLEMENTING SAP}

* Increase in yield by timely crushing good quality and matured cane.

Benefits from the supply of the inputs to the farmers.

* Farmer's loyalty increase.

* Planning, budgeting and achievement have meager deviation.

* Re-deployment of the human resources.

* Staggered plantation helps the factory to crush throughout the crushing season.

\section{Conclusion}

Any module in the ERP system is implemented by the consultants engaged by the company. After the implementation (installation), the system has to be used by the employees of the company who are called the end-users. They have to be accustomed to the way the system works to get optimum benefit from the system. Using the software at the end or after the implementation is an End User is the one who performs transactions in SAP after it goes live.

Since the financial position of Indian farmers is very weak, the loan facility provided by the industries through Bank encourages the farmers to grow more cane and also motivates the farmers. The loan amount is paid immediately to the Bankers from the farmers through factory will also increase the transactions of the Bank in turn both bankers and farmers are mutually benefitted.

VI

Acknowledgements

Authors are Thankful to Sri.M.Ravi,Asst.GeneralManager (production) andSri.K.Murali, Asst.Manager (Cane) Bannariamman Sugars Ltd, Nanjanagud for Technical discussion. 


\section{Journal papers:}

\section{REFERENCES}

[1] Chandraju,S, Raviprasad.B and ChidanKumar.C.S 'Studies on the implementation of System Application Product (SAP) Materials Management (MM-Module) in Sugar cane Cultivation and Harvesting’. Asian Journal of Research in Business Economics and Management, 2012.Vol 2, issue 3 pp 73-79.

[2] Chandraju,S, Raviprasad.B and ChidanKumar.C.S 'ABC classification Frame work order Goods receipt and transaction codes for implementation of System Application Product (SAP) Materials Management (MM-Module) in Sugar Industry’ International Conference on Engineering Technology and Management",2012 in press.

[3] Chandraju,S, Raviprasad.B and ChidanKumar.C.S“Implementation of system applicationproduct (sap) materials management (mmmodule) for invoice verification, material group and material master record in sugar industry"International journals of multi research Academy" (IJMRA) 2012 in press.

[4] Chandraju,S, Raviprasad.B and ChidanKumar.C.S"Implementation of system application product (sap) materials management (mm-module) for Material requirement planning (MRP) in Sugar Industry"International journals of Scientific and Research Publications (IJSRP) 2012 in press.

Books:

[5] Dobler, Donald W; Burt, David N (1996). Purchasing and Supply Management, Text and Cases (Sixth Edition ed.). Singapore: McGraw-Hill. pp. 70.

[6] SAP® MM: Questions and Answers by Kogent Learning Solutions, Inc.

[7] ASM Technologies for IT solutions to sugar cane industries,

[8] Basic informations from M/s,BannariammanSugars,Nanjanagud.

[9] Case study report on Inventory Management by HRIHE, Hassan. 